\title{
COMMUNICATION WITH PARENTS OF CHILDREN WITH SPECIAL NEEDS WHO HAVE DIFFICULTY ACHIEVING OR ARE UNABLE TO ACHIEVE THE MINIMUM GOALS IN REGULAR PRIMARY SCHOOL ${ }^{i}$
}

\author{
Magdalena Tehovnik ${ }^{\mathrm{ii}}$ \\ Special Education Teacher, \\ Elementary School Preserje near Radomlje, \\ Slovenia
}

\begin{abstract}
:
Good verbal and non-verbal communication is of paramount importance for maintaining and building relationships. However, educators need to be as much as possible attentive when talking to parents of children with learning difficulties to such an extent that they will not be able to complete the regular program. A teacher for children with special needs and a teacher who talk with parents about pupil's problems and new opportunities in a program with a lower educational standard must have a high level of empathy. They need to be aware that these are injured parents and they need to be able to decide when an individual parent is ready for such information. Most importantly, parents have to feel that we really only want the best for the child and them. In this case, they will be ready for re-education sooner and the child will have fewer unnecessary negative experiences.
\end{abstract}

Keywords: regular primary school, minimum standards, parents of children with learning difficulties, re-education, program with a lower educational standard

\section{Povzetek:}

Dobra verbalna in neverbalna komunikacija je za vzdrževanje in gradnjo odnosov izrednega pomena. $Z$ vzporedno držo telesa in očesnim kontaktom sočutno komuniciramo z vsemi starši. Pri pogovoru s starši otrok s težavami pri učenju v takšni meri, da rednega programa ne bodo zmogli, pa morajo biti še toliko bolj čuteči. Specialni pedagog in učitelj, ki staršem predstavita težave in nove možnosti na programu z nižjim izobrazbenim standardom, morata imeti veliko mero sposobnosti vživljanja. Zavedati se morata, da so to ranjeni starši in znati morata presoditi, kdaj je posamezen starš pripravljen na kakšno informacijo. Najpomembneje je, da starši čutijo, da resnično želimo

\footnotetext{
i KOMUNIKACIJA S STARŠI OTROK S POSEBNIMI POTREBAMI, KI LE S TEŽAVO DOSEGAJO ALI PA MINIMALNIH CILJEV V REDNI OSNOVNI ŠOLI NE ZMOREJO DOSEGATI

ii Correspondence: email mepz.dobrova@gmail.com
} 
otroku in njim le najboljše. Čutiti morajo našo pomoč. $V$ tem primeru bodo na prešolanje pripravljeni prej in otrok bo tako imel manj nepotrebnih negativnih izkušenj.

Ključne besede: redna osnovna šola, minimalni standardi, starši otrok s težavami pri učenju, prešolanje, program z nižjim izobrazbenim standardom

\section{Introduction}

Humans are social beings and we use communication to coexist with others. When we want to tell something to others, we do so verbally and nonverbally. It always matters how we say something; for parents of children who, despite their immense effort and all the help at home and elsewhere, fail to achieve minimum goals and are involved in regular primary school, however, the way we choose words is of paramount importance, as these parents are often severely injured. Only with a great deal of ability to empathize with another will we be able to perceive what kind of message they are willing to accept at a given moment; depending on which stage of acceptance or non-acceptance of the child's problems are some parents (denial, anger, guilt, acceptance). However, we always say the most with non-verbal communication, which is essential for such sensitive topics. We express our affection with the posture itself (parallel body orientation towards the interlocutor) and with eye contact. Good communication means coherence between verbal and non-verbal communication. When there is no such consistency, it means that someone is not saying what he or she thinks or feels. The way of communication shows the relationship between the interlocutors, and the foundation of the relationship must be mutual respect. And these parents need to feel this harmony well if we want them to listen to us to the extent that they start preparing themselves for the re-education step, which is certainly not an easy step, but in some cases it is the best move for the child and his family. Parents really need to feel that we are on their side, that if necessary, we also defend them against some unappropriate reactions by some teachers and that we will provide them with all the necessary help in further education at the current school and when the conditions are right - also in the retraining process.

Before the parents enter into the dialogue, a contact is established between the teacher and the student. If the child trusts the teacher and the special pedagogue, if he or she feels that the two of them only wish him or her well, a good basis is laid so that the problems and possible solutions are presented to the parents as well. Of course, the teacher and the special pedagogue cooperate with the parents from the first day of the child's schooling, but a solid pedagogical triangle is established only when there is a regular and appropriate communication between the subjects. A message is appropriate when it includes all the important information needed for the receiver, in this case the parent, to understand the message. Sensitive parents of children who find the program difficult, or. unable to follow, will be able to accept early information about the possibility of schooling in a program with a lower educational standard, while parents, who care more about the opinion of the environment than the child's happiness, will need a lot of 
time or they will never accept this, and the child and the whole family will continue to suffer all this time. The first group of children will soon move to a more suitable program for them, where children will be able to be successful, happy, complete an education, gain a profession and later be satisfied adults. The second group will probably complete the regular primary school program one way or another but their success and ability to acquire a profession, as well as their satisfaction and happiness in adulthood, are highly questionable.

Students, who want to become future teachers prepare for quite some time how to communicate with children, while little time is devoted to communication with parents, which is the most sensitive part of the educational triangle. Modern school policy directs the development of family-school relations in the direction of a partnership in which the school and the home share responsibility for the development and progress of the student. In addition to the maximum possible ability of the expert's empathy, which is fully innate and nurtured until adulthood, in this communication it is essential to constantly check the understanding of the information given by parents and at the same time check our understanding of the information received in the sense: "If I understood you correctly you say that...", which an individual can learn. Nevertheless, parents will prefer to talk to a special and rehabilitation pedagogue about such a delicate topic as the possibility of transferring a child to a program with a lower educational standard, who will be able to present the new program and summarize the procedures for such a move. In good communication with parents, teamwork and the support of the child's class teacher are assential.

Every parent wants his child to be successful. When problems arise and when, despite the generous help of school professionals and parents at home, possibly with the help of various school instructors, the child is not successful, for many parents this is a great frustration that individuals face differently. Parents of children with special needs are a vulnerable group, so communication with them is a really sensitive area, and the issue of not achieving minimum goals is all the more delicate. The ability to empathize, a sincere intention to help the family, and a genuine relationship with the student are the basis for successful collaboration, and parents need to feel our generous help to the child and them.

\section{Conflict of Interest Statement}

The author declares no conflicts of interests.

\section{About the Author}

Magdalena Tehovnik completed her studies in special education. As a professor of special education, she first gained experience at lower educational standards in education, and for ten years she has been working as a special pedagogue at a regular primary school in Preserje near Radomlje. At Glasser Quality School, employees emphasize the relationship between all those involved in the process of upbringing and education, taking into accounts the theory of choice and connecting habits. In this 
environment, employees are therefore even more in favor of the way they work with students, which they introduce in the counseling service, as they contribute to the better well-being of students at school and thus also to better overall results.

\section{References}

Intihar, D., Kepec, M. (2002). Partnerstvo med šolo in domom. Ljubljana: Zavod Republike Slovenije za šolstvo.

Kalin, J., Resman, M., Šteh, B., Mrvar, P., Govekar-Okoliš, M. in Mažgon, J. (2009). Izzivi in smernice kakovostnega sodelovanja med šolo in starši. Ljubljana: Znanstvena založba Filozofske fakultete Univerze v Ljubljani.

Lepičnik Vodopivec, J. (2012). Teorija in praksa sodelovanja s starši. Ljubljana: Pedagoška fakulteta. 
Creative Commons licensing terms

Authors will retain the copyright of their published articles agreeing that a Creative Commons Attribution 4.0 International License (CC BY 4.0) terms will be applied to their work. Under the terms of this license, no permission is required from the author(s) or publisher for members of the community to copy, distribute, transmit or adapt the article content, providing a proper, prominent and unambiguous attribution to the authors in a manner that makes clear that the materials are being reused under permission of a Creative Commons License. Views, opinions and conclusions expressed in this research article are views, opinions and conclusions of the author(s). Open Access Publishing Group and European Journal of Special Education Research shall not be responsible or answerable for any loss, damage or liability caused in relation to/arising out of conflict of interests, copyright violations and inappropriate or inaccurate use of any kind content related or integrated on the research work. All the published works are meeting the Open Access Publishing requirements and can be freely accessed, shared, modified, distributed and used in educational, commercial and non-commercial purposes under a Creative Commons Attribution 4.0 International License (CC BY 4.0). 